\title{
Pengembangan Produk Fashion Menggunakan Material Kertas Bekas Kantong Semen Dengan Pendekatan Low-Impact Use
}

\author{
Astrid Jenifer ${ }^{*}$, Imam Santosa2, Imam Damar Djati \\ 1,2,3 Program Magister Desain, Fakultas Seni Rupa dan Desain, Institut Teknologi \\ Bandung, Bandung, Indonesia
}

\begin{abstract}
Garment material which is processed as a basic material for fashion products is very closely related to environmental problems that occur at this time. By encouraging the idea of sustainability through a low-impact use approach that focuses on the cleaning process, cement bags used paper are made into utilitarian materials that will produce products that cannot be washed. Cement bags used paper have good quality because they can withstand loads of up to $40 \mathrm{~kg} /$ sack and are generally used as wrappers or bags that function as covers. However, cement bags used paper tend not to be used or reprocessed into functional products. Therefore, this research aims to design and realize fashion products by recognizing the character and utilizing the potential of cement bags used paper to become products with high use values. The method used in this research is coloring experiments, testing materials, and exploring shapes and visuals. Material processing is applied using gyre and macrame techniques. The final result of this research is an alternative raw material from cement bags used paper for fashion products.
\end{abstract}

Keywords: cement bags used paper, low-impact use, gyre technique, macramé technique.

$\begin{array}{ll}\text { *Astrid Jenifer } & \\ \text { Email } & \text { : astridjenifer@gmail.com } \\ \text { Address } & \text { : Program Studi Magister Desain, Fakultas Seni Rupa dan Desain } \\ & \text { Institut Teknologi Bandung } \\ & \text { Jalan Ganesha no.10, Bandung, West Java - Indonesia } 40132\end{array}$




\title{
Pengembangan Produk Fashion Menggunakan Material Kertas Bekas Kantong Semen Dengan Pendekatan Low-Impact Use
}

\author{
Astrid Jenifer, Imam Santosa, Imam Damar Djati
}

\section{PENDAHULUAN}

Fashion menjadi bagian yang tidak dapat dilepaskan dari penampilan dan gaya keseharian. Produk - produk yang dikenakan seperti baju dan aksesoris bukanlah sekedar hiasan dan penutup tubuh, namun menjadi sebuah alat komunikasi untuk menyampaikan identitas pribadi. Namun, generasi saat ini mampu membebaskan diri dari konstruksi sosial dan budaya yang mendikte perilaku kita dalam beberapa abad terakhir. Pemikiran tersebut telah pudar dengan berkembangnya gaya jalanan atau streetwear style saat ini.

Streetwear style merupakan gaya pakaian yang dikenakan banyak orang karena dianggap sebagai kode pakaian yang lebih santai. Trend ini mengungkapkan tentang budaya kontemporer bahwa orang - orang mencari keotentikan dan realitas. Yaitu pemikiran bahwa kenyamanan merupakan kebebasan pemakai. Kenyamanan memakai produk pada dasarnya adalah ketika kondisi pikiran kita berada pada tingkat stress terendah. Melalui kebebasan atas keotentikan ini tercipta fokus untuk meningkatan dan mengembangkan material utilitarian (berguna atau bermanfaat) seperti pemanfaatan kertas bekas kantong semen menjadi material premium yang dapat digunakan pada produk fashion.

Menurut Fletcher dan Groose, dunia kita selalu berkaitan dengan dunia material. Material yang digunakan menjadi sangat penting untuk mengembangkan ide berkelanjutan. Menghubungkan kita pada isu - isu besar saat ini seperti perubahan iklim, penciptaan limbah, dan kesulitan air. Melalui pendekatan low - impact use yang terfokus pada mencuci dan merawat pakaian mampu meminimalisasi dampak pada lingkungan dan mendukung ide keberlanjutan [1]. Umumnya segala material yang diolah dan diproduksi khususnya merupakan material sintesis yang terbuat dari bahan kimia dan memiliki dampak yang besar terhadap lingkungan. Salah satu kertas kantong semen, setelah dilakukan analisa kimia terhadap hasil limbah padat tersebut ternyata memiliki unsur - unsur yang mirip dengan komposisi semen seperti adanya kandungan Aluminium Oksida $\left(\mathrm{Al}_{2} \mathrm{O}_{3}\right)$, KalsiumOksida ( $\left.\mathrm{CaO}\right)$, Magnesium Oksida (MgO), SulfurTrioksida $\left(\mathrm{SO}_{3}\right)$, Silikon dioksida $\left(\mathrm{SiO}_{2}\right)(\mathrm{LPKI}, 2005)$ yang merupakan senyawa yang dapat digunakan sebagai bahan dasar pembuat semen, dimana diketahui bahwa bahan dasar semen saat ini tidak dapat diperbaharui sehingga diperlukan bahan dasar pengganti yang dapat dijamin ketersediaannya [2].

Kertas bekas kantong semen umumnya dimanfaatkan menjadi kantong semen dan memiliki fungsi sebagai 'covering'. Namun, cenderung tidak dimanfaatkan atau diolah kembali menjadi produk fungsional, sehingga usia pakainya pun tergolong singkat dan tersisa menjadi 'sampah'. Padahal memiliki potensi lain dengan kualitas bahan yang tergolong sangat baik di lihat dari sisi ketebalan maupun kepadatan seratnya yang dapat difungsikan menjadi kantong pengemas semen dan menahan beban mencapai $40 \mathrm{~kg} / \mathrm{sak}$.

Terdapat banyak cara untuk pemanfaatan kertas bekas kantong semen sendiri misalnya didaur ulang dan dibuat aneka ragam produk kerajinan, bahkan telah dikembangkan untuk bahan beton ringan [3]. Selain itu, kantong semen telah 
dimanfaatkan oleh UKM atau industri rumahan seperti UKM Viora Tanggulangin di Sidoarjo menjadi berbagai kerajinan fungsional, seperti tas, sepatu, dan dompet [4]. Namun, dari sudut pandang konsumen produk cenderung kurang diminati terlebih dipakai untuk keperluan mode atau fashion. Hal ini dilatar belakangi bahan kantong semen bekas yang terkesan murah dan desain pasaran yang meniru produk yang sudah ada sebelumnya.

Berdasarkan permasalahan diatas, maka muncul gagasan untuk menciptakan material utilitarian yang mendukung ide keberlanjutan dengan mengoptimalkan karakteristik dari kertas bekas kantong semen untuk menciptakan produk inovatif yang bernilai tinggi melalui pendekatan low-impact use (pendekatan berdampak rendah).

\section{METODE PENELITIAN}

Penelitian ini membahas pengembangan produk fashion menggunakan material kertas bekas kantong semen dan pengujian kuat tarik material sebagai bahan alternatif produk fashion menggunakan metode pendekatan kuantitatif.

Dalam hal ini hasil pengembangan produk fashion merupakan variabel dependen yang dipengaruhi oleh pengolahan kertas bungkus semen yang merupakan variable independen. Pengaruh hal tersebut diperkuat dengan adanya variable moderator berupa preferensi target market terhadap hasil pengolahan kertas bungkus semen. Teknik pengumpulan data kuantitatif didukung dengan beberapa data numerik dalam melakukan proses eksperimen dan eksplorasi. Pengumpulan data kuantitatif dilakukan dengan kuesioner melalui website Google Form dan dibagikan online. Terdapat teknik lain yaitu eksperimen pewarnaan, ekplorasi bentuk dan visual, serta pengujian kuat tarik dengan mengetahui besar ketahanan beban terhadap material. Kemudian dari data yang didapatkan akan dilakukan pengembangan desain produk. Untuk eksplorasi, teknik yang diaplikasikan yaitu teknik makrame. Selain itu setelah produk rancangan selesai akan dilakukan aspek pengujian standar tekstil untuk produk fashion secara manual, pengujian estetika dan usability produk, dan pengujian berdasarkan pendekatan low impact use.

\section{TAHAP PEWARNAAN}

\section{Eksperimen Pewarnaan Kertas Bekas Kantong Semen}

Tabel 1 Eksperimen Pewarnaan

\begin{tabular}{ll}
\hline No & \multicolumn{1}{c}{ Keterangan } \\
\hline 1. & $\begin{array}{l}\text { Material dibuka dan digunting } \\
\text { selebar 2cm memanjang secara } \\
\text { vertical. }\end{array}$ \\
\hline
\end{tabular}


3.

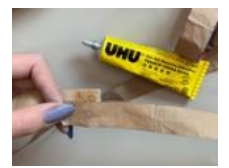

Material disambung satu persatu

hingga menghasilkan potongan

panjang.

4.

Kayu secang dipersiapkan sebanyak 55 gran dan air 3 liter.

5.

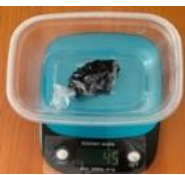

Pasta pewarna indigo disiapkan sebanyak 45 gram dan air 3 liter.

6.

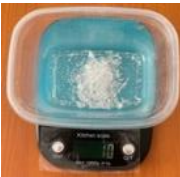

Siapkan mordant berupa tawas

10 gram dan air 2 liter.

7.

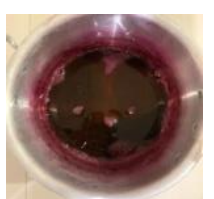

Kayu secang direbus selama 45

menit hingga zat pewarna keluar.

8.

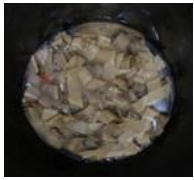

Potongan material direndam

dalam air tawas selama 30

menit.

9.

Pewarna alam secang direbus sebanyak $600 \mathrm{ml}$ didalam air 2,4 liter. 
10.

Proses pencelupan dalam pewarna secang selama 45 menit.

11.

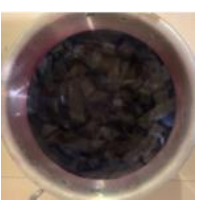

lakukan proses pencelupan yang sama pada pewarna indigo

selama 45 menit

12.

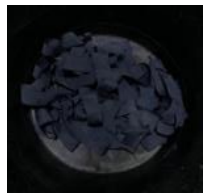

Potongan material dicelupkan ke

dalam pewarna indigo dan

didiamkan hingga mengering.

13.

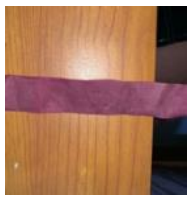

Setelah pencelupan pada

pewarna alam secang juga

diangkat dan didiamkan hingga

mongering.

\section{Uji Kepekatan Warna Material Kertas Bekas Kantong Semen}

Proses pewarnaan pada pilinan akan dilakukan bertahap selama 5 menit, 15 menit, 30 menit, 45 menit, dan 60 menit. Hasil pewarnaan kemudian dibandingkan menggunakan lux light meter pro, apakah perendaman dalam waktu yang singkat hingga waktu yang lebih lama akan mendapatkan warna yang semakin pekat atau berubah.

Tabel 2 Uji kepekatan warna

\begin{tabular}{ll}
\hline No. Tahapan & \multicolumn{1}{c}{ Keterangan } \\
\hline Siapkan potongan material yang \\
telah dilakukan pewarnaan \\
sebelumnya.
\end{tabular}


3.

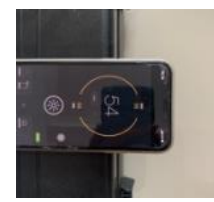

Buka aplikasi dan tempatkan diatas media penahan untuk

memudahkan pemindaian warna

Letakkan potongan material searah

4.

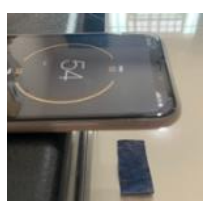

dengan lensa kamera untuk

memindah kepekatan warna

Setelah material diposisikan

5.

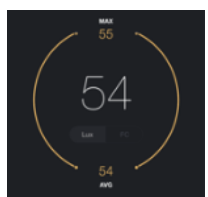

dengan tepat, tekan gambar light pada aplikasi

Kemudian lakukan langkah

berulanh hingga mengetahui

kepekatan warna material.

\section{Hasil Eksperimen Pewarna Alam}

Tabel 3 Hasil Eksperimen Pewarnaan

\begin{tabular}{|c|c|c|c|}
\hline \multirow[b]{2}{*}{ Waktu } & \multicolumn{3}{|c|}{ Kepekatan } \\
\hline & $\begin{array}{l}\text { Tanpa mordant } \\
\text { (pewarna indigo) }\end{array}$ & $\begin{array}{l}\text { Dengan mordant } \\
\text { (pewarna } \\
\text { secang) }\end{array}$ & $\begin{array}{c}\text { Dengan } \\
\text { mordant } \\
\text { (pewarna } \\
\text { indigo) }\end{array}$ \\
\hline \multicolumn{4}{|l|}{5 menit } \\
\hline & 75 Lux & 71 Lux & 52 Lux \\
\hline \multicolumn{4}{|l|}{15 menit } \\
\hline & 75 Lux & 74 Lux & $53 \operatorname{Lux}$ \\
\hline \multicolumn{4}{|l|}{30 menit } \\
\hline & 74 Lux & 75 Lux & $54 \operatorname{Lux}$ \\
\hline
\end{tabular}




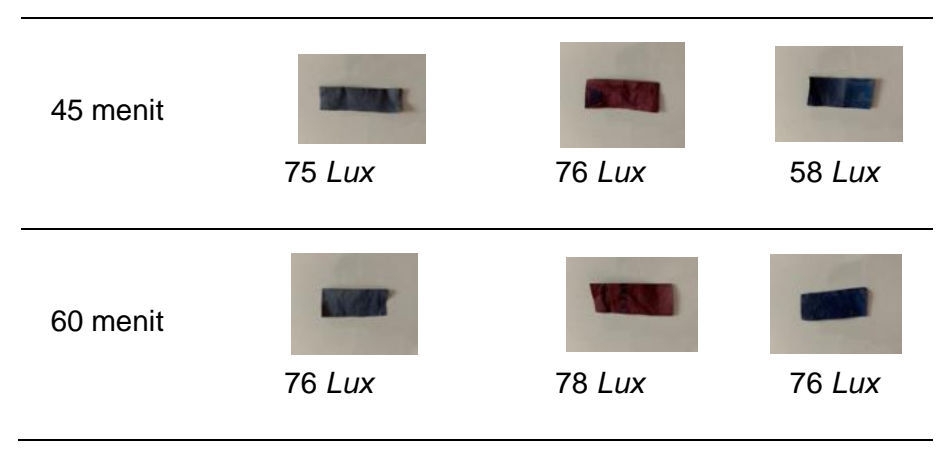

\section{PERCOBAAN PEMILINAN}

\section{Tahap Pemilinan}

Tabel 4 Proses Tahap Pemilinan

\begin{tabular}{ll}
\hline No. & \multicolumn{1}{c}{ Keterangan } \\
\hline 1. & $\begin{array}{l}\text { Potongan material diangin - } \\
\text { anginkan hingga setengah } \\
\text { mongering. }\end{array}$ \\
\hline 2. & $\begin{array}{l}\text { Pada permukaan yang rata material } \\
\text { digulung dengan telapak tangan. }\end{array}$ \\
\hline 4. & $\begin{array}{l}\text { Lakukan pemilinan berulang kali } \\
\text { hingga menjadi pilinan panjang. }\end{array}$ \\
\hline & $\begin{array}{l}\text { Pilinan yang dibentuk kemudian } \\
\text { dikeringkan dan dirapikan }\end{array}$ \\
\hline
\end{tabular}

\section{Uji Kuat Tarik Pilinan}

Tabel 5 Proses Uji Kuat Tarik Pilinan

\begin{tabular}{lll}
\hline No. & Tahapan & \multicolumn{1}{c}{ Keterangan } \\
\hline & & $\begin{array}{l}\text { Siapkan alat penunjang uji yaitu } \\
\text { timbangan digital dengan satuan } \\
\text { 1. }\end{array}$ \\
\hline
\end{tabular}


2

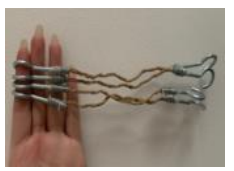

Siapkan tiap pilinan dengan

memasang kaitan hook pada ujung

pilinan

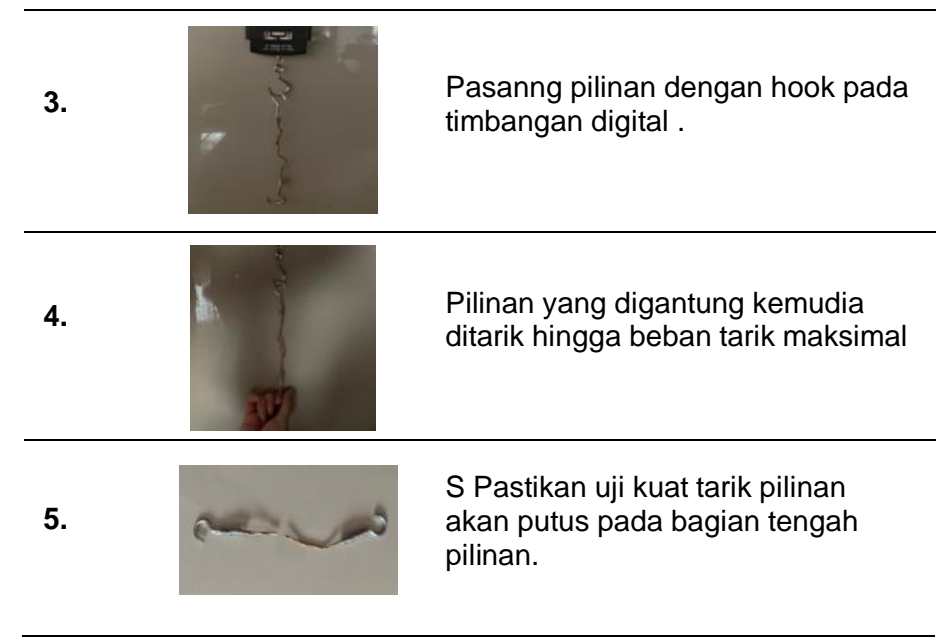

Data Pengujian Kuat Tarik Pilinan

Tabel 6 Hasil Pengujian Kuat Tarik

\begin{tabular}{llc}
\hline $\begin{array}{c}\text { No. } \\
\text { Spesimen }\end{array}$ & \multicolumn{1}{c}{ Keterangan } & Beban tarik \\
& & rata - rata $(\mathrm{kg})$ \\
\hline A-1 & Uji tarik pilinan keadaan kering & 4,588 \\
\hline B-2 & Uji tarik pilinan keadaan basah & 0,240 \\
\hline C-3 & $\begin{array}{l}\text { Uji tarik pilinan warna keadaan } \\
\text { kering }\end{array}$ & 5,581 \\
\hline D-4 & $\begin{array}{l}\text { Uji tarik pilinan setelah dicuci atau } \\
\text { dibasahi }\end{array}$ & 4,978 \\
\hline Rata - rata & \multicolumn{3}{l}{3,846} \\
\hline
\end{tabular}

Data Pengujian Kuat Tarik Pilinan Berdasarkan Zat Perekat

Tabel 7 Hasil Uji Kuat Tarik Berdasarkan Zat Perekat

\begin{tabular}{|c|c|c|}
\hline $\begin{array}{l}\text { No. } \\
\text { Spesimen }\end{array}$ & Keterangan & $\begin{array}{l}\text { Beban tarik } \\
\text { rata - rata }(\mathrm{kg})\end{array}$ \\
\hline A-2 & $\begin{array}{l}\text { Pilinan dengan all purpose } \\
\text { adhesive }\end{array}$ & 4,675 \\
\hline B-2 & Pilinan dengan white adhesive & 5,951 \\
\hline C-2 & $\begin{array}{l}\text { Pilinan dengan multi purpose } \\
\text { adhesive }\end{array}$ & 5,532 \\
\hline
\end{tabular}




\begin{tabular}{ccc}
\hline D-2 & Pilinan dengan liquid adhesive & 4,075 \\
\hline & Rata - rata & 5,058 \\
\hline
\end{tabular}

\section{UJI MATERIAL MELALUI PENGUJIAN MANUAL DAN USER REVIEW}
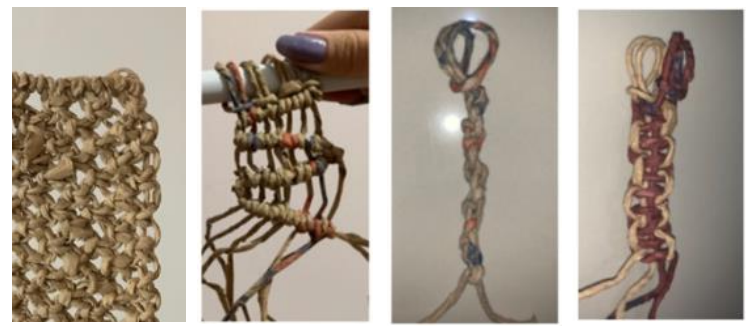

Gambar 1 Hasil Eksplorasi

Proses berikutnya adalah melakukan uji material, namun sebelumnya material diolah menggunakan makrame terlbih dahulu. Dihasilkan 6 eksplorasi material dengan teknik makrame ditunjukkan pada gambar 1 . Hasil eksplorasi pada gambar 1 lalu dilanjutkan dengan pengujian secara manual untuk melihat kemampuan material makrame dari pilinan kertas bekas kantong semen sebagai penentu produk fashion yang cocok sebagai penerapan hasil eksplorasi. Aspek pengujian mengikuti standar pengujian tekstil untuk produk fashion dalam batasan normal penggunaan produk fashion.

\section{Hasil Tanggapan User}

Tabel 8 Tanggapan User atau Responden

\begin{tabular}{|c|c|c|c|c|}
\hline \multirow[b]{3}{*}{ Aspek } & \multicolumn{4}{|c|}{ Material } \\
\hline & 1 & 2 & 4 & 6 \\
\hline & Presers & tou & 量 & \\
\hline $\begin{array}{c}\text { Karakteris } \\
\text { tik }\end{array}$ & $\begin{array}{l}\text { Tebal, } \\
\text { kaku, kuat }\end{array}$ & $\begin{array}{l}\text { Lentur, } \\
\text { tebal, kuat. }\end{array}$ & $\begin{array}{l}\text { Tebal, } \\
\text { kaku, kuat }\end{array}$ & $\begin{array}{l}\text { Lentur } \\
\text { rapuh }\end{array}$ \\
\hline $\begin{array}{c}\text { Kenyama } \\
\text { nan }\end{array}$ & Kasar & Kasar & Kasar & Kasar \\
\hline Estetika & $\begin{array}{l}\text { Bentuk } \\
\text { menarik }\end{array}$ & $\begin{array}{l}\text { Bentuk dan } \\
\text { warna unik } \\
\text { dan } \\
\text { menarik }\end{array}$ & $\begin{array}{l}\text { Warna } \\
\text { menarik }\end{array}$ & $\begin{array}{l}\text { Bentuk } \\
\text { dan } \\
\text { warna } \\
\text { unik dan } \\
\text { menarik }\end{array}$ \\
\hline $\begin{array}{l}\text { Rekomen } \\
\text { dasi } \\
\text { pemanfaa } \\
\text { tan }\end{array}$ & $\begin{array}{l}\text { Pakaian, } \\
\text { tas, dan } \\
\text { dompet }\end{array}$ & pakaian & $\begin{array}{l}\text { Dompet } \\
\text { dan tas }\end{array}$ & $\begin{array}{l}\text { Dompet } \\
\text { dan tas }\end{array}$ \\
\hline
\end{tabular}




\section{Karakteristik hasil pengujian}

Tabel 9 Karakteristik Material

\begin{tabular}{|c|c|c|c|}
\hline Material & Karakteristik & Keunggulan & Kekurangan \\
\hline 3 & $\begin{array}{l}\text { - Tebal } \\
\text { - Kaku } \\
\text { - Kuat } \\
\text { - Menyerap air } \\
\text { - Kasar }\end{array}$ & $\begin{array}{l}\text { - Bentuk } \\
\text { menarik }\end{array}$ & $\begin{array}{l}\text { - Kasar } \\
\text { - Tidak fleksibel }\end{array}$ \\
\hline 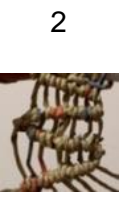 & $\begin{array}{l}\text { - Fleksibel } \\
\text { - Tebal } \\
\text { - Menyerap air } \\
\text { - Kuat } \\
\text { - Kasr }\end{array}$ & $\begin{array}{l}\text { Bentuk dan } \\
\text { warna yang } \\
\text { unik dan } \\
\text { menarik }\end{array}$ & $\begin{array}{ll}\text { - } & \text { Fleksibilitas } \\
\text { terbatas } \\
\text { - Kasar }\end{array}$ \\
\hline 4 & $\begin{array}{l}\text { - Tebal } \\
\text { - Kaku } \\
\text { - Kuat } \\
\text { - Menyerap air } \\
\text { - Kasar }\end{array}$ & $\begin{array}{l}\text { - Warna yang } \\
\text { menarik }\end{array}$ & $\begin{array}{l}\text { - Kasar } \\
\text { - Tidak fleksibel }\end{array}$ \\
\hline$\frac{5}{5}$ & $\begin{array}{l}\text { - Fleksibel } \\
\text { - Rapuh } \\
\text { - Menyerap air } \\
\text { - Kasar }\end{array}$ & $\begin{array}{l}\text { Bentuk dan } \\
\text { warna yang } \\
\text { unik dan } \\
\text { menarik }\end{array}$ & $\begin{array}{l}\text { - } \text { Rapuh } \\
\text { - } \text { Fleksibilitas } \\
\text { - } \text { Karbatas } \\
\text { - Kasar }\end{array}$ \\
\hline
\end{tabular}

\section{PERANCANGAAN PRODUK FASHION}

\section{Konsep Perancangan Desain}

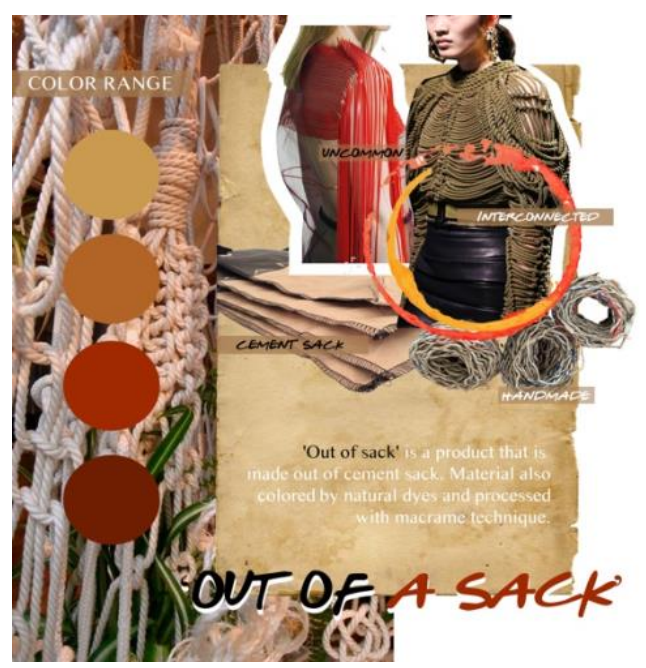

Gambar 1 Moodboard

Produk rancangan yang diciptakan melalui pendekatan low-impact use yaitu memperhatikan aspek desain rendah cucian, tidak dicuci, desain untuk noda, dan penyetrikaan daya rendah.

Desain divisualisasikan dengan moodboard yang berjudul 'Out Of Sack' dengan kata kunci cement sack, handmade, interconnected, dan uncommon. Warna yang dipilih yaitu warna natural dari kertas bekas kantong semen yang sengaja dibiarkan agar 
menonjolkan ke autentikan serta keaslian material dan warna merah kecokelatan berasal dari zat pewarna alam secang. Proses produksi dilakukan dengan sketsa produk terlebih dahulu. Proses desain dilakukan berdasarkan sifat dan karakteristik material kertas bekas kantong semen yang telah diteliti dan trend yang telah dianalisis yang kemudian disesuaikan dengan konsep desain. Desain dibuat melalui pertimbangan karakteristik dan sifat material dalam wujud simpul atau makrame. Lalu hasil sketsa diaplikasikan pada dua produk, yaitu produk fashion dan tas.

\section{Penerapan Teknik Makrame}

Pada tahap ini hasil uji kuat tarik, eksperimen pewarnaan, dan eksplorasi bentuk dan visual material kertas bekas kantong semen dengan teknik makrame kemudian diwujudkan menjadi produk tas dan busana fashion. Pilinan yang digunakan untuk perwujudan desain ini marupakan hasil pemilinan dan penggintiran secara manual menggunakan tangan karena mendukung prinsip eco-efisiensi.

\section{Produk Fashion}

Proses pembuatan produk fashion dilakukan dengan penerapan teknik makrame. Prinsip desainnya adalah Top dengan siluet fit to body. Lengan menggunakan simpul gordin dan pada bagian pundak kebawah pilinan dibiarkan memanjang. Panjang baju diatas lutut dengan pilinan yang dibiarkan terurai dari pinggang memanjang kebawah. Berikut adalah hasil produk fashion :
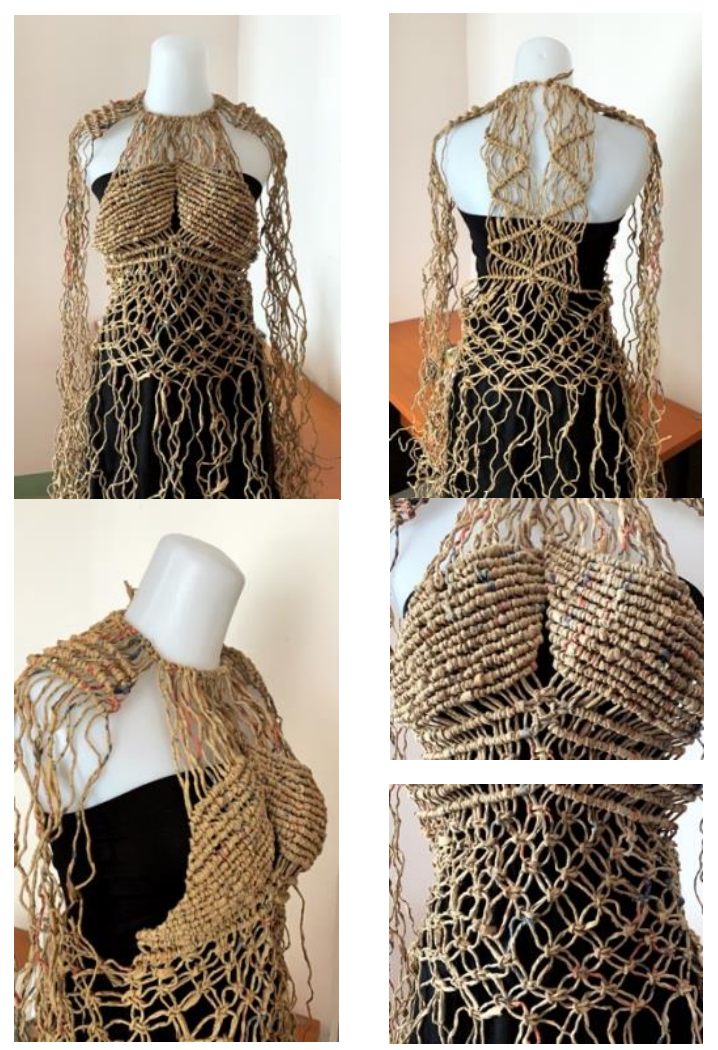

Gambar 4 Tampak Depan, Belakang, Samping, Dan Detail Busana.

\section{Produk Tas}

Proses pembuatan dilakukan dengan penerapan teknik makrame, dimana terdapat penggabungan material menggunakan pewarna secang dan warna natural. Tas memiliki bentuk persegi panjang, dengan potongan ditengah pada bagian utama dan penutup tas. Untuk bagian penutup tas berbentuk segitiga fan pilinan dibiar kan memanjang keluar pada bagain ujungnya. Ukuran tas $20 \mathrm{~cm} \times 10 \mathrm{~cm}$. Berikut adalah hasil produk tas : 


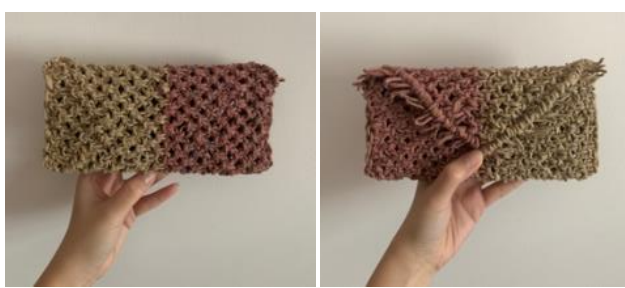

Gambar 5 Tampak Depan Dan Belakang Produk Tas

\section{ANALISIS DESAIN}

\section{Analisis Desain dan Tanggapan Responden Terhadap Estetika dan Usability Produk}

Tabel 10 Aspek Review Analisis Desain

\begin{tabular}{|c|c|c|}
\hline No. & Aspek review & Pertanyaan \\
\hline \multirow[t]{3}{*}{1.} & \multirow{3}{*}{$\begin{array}{c}\text { Kenyamanan dan } \\
\text { kemudahan } \\
\text { pemakaian }\end{array}$} & Apa produk nyaman digunakan? \\
\hline & & $\begin{array}{l}\text { Apakah produk mudah dibuka } \\
\text { tutup atau dipakai - lepaskan? }\end{array}$ \\
\hline & & $\begin{array}{l}\text { Bagaimana perbandingan produk } \\
\text { sejenis pada umumnya? }\end{array}$ \\
\hline \multirow[t]{2}{*}{2.} & \multirow{2}{*}{ Kegunaan } & $\begin{array}{l}\text { Apakah anda tertarik untuk } \\
\text { menggunakan prdouk ini? }\end{array}$ \\
\hline & & $\begin{array}{l}\text { Kemanakah produk ini cocok } \\
\text { digunakan? }\end{array}$ \\
\hline \multirow[t]{2}{*}{3.} & \multirow{2}{*}{ Estetika } & $\begin{array}{l}\text { Apa pendapat anda tentang bentuk } \\
\text { produk ini? }\end{array}$ \\
\hline & & $\begin{array}{l}\text { Apa pendapat anda terhadap simpul } \\
\text { dan warna pada produk ini? }\end{array}$ \\
\hline
\end{tabular}

Sebagaian besar responden berpendapat bahwa produk tas nyaman untuk digunakan, mudah dibuka tutup, dan memiliki berat produk yang sama dibandingkan dengan produk sejenis. Sedangkan untuk produk busana, responden merasa nyaman memakainya namun tidak dalam jangka waktu yang lama dan harus menggunakan furing atau pelapis pada atasan, penggunaan produk pun tergolong sulit untuk dilepas pakai. Berdasarkan user review rata - rata responden tertarik untuk memakai kedua produk, produk tas dapat dipakai pada acara formal maupun semi formal. Sedangkan produk busana hanya dapat dipakai pada acara tertentu, seperti event fashion. Secara keseluruhan responden berpendapat bahwa kedua produk merupakan produk yang unik, menarik, dan kreatif. 


\section{Analisis Desain Terhadap Pendekatan Low - Impact Use}

Pengujian produk melalui pendekatan low - impact use mencakup desain untuk rendah pencucian, desain yang tidak dicuci, desain untuk noda, dan desain dengan penyetrikaan daya rendah.

Tabel 11 Hasil Aspek Review Terhadap Pendekatan Low-Impact Use

\begin{tabular}{|c|c|c|}
\hline No. & Aspek review & Keterangan \\
\hline 1. & $\begin{array}{l}\text { Desain rendah } \\
\text { pencucian (design } \\
\text { for low launder) }\end{array}$ & 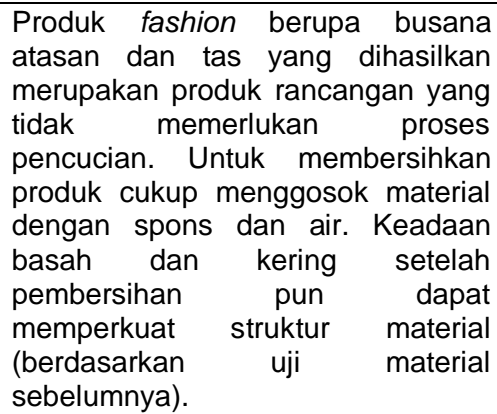 \\
\hline 2. & $\begin{array}{l}\text { Desain tidak dicuci } \\
\text { (no wash) }\end{array}$ & $\begin{array}{l}\text { Desain produk dan teknik olah } \\
\text { dengan material kertas bekas } \\
\text { kantong semen yang diaplikasikan } \\
\text { tidak perlu diberi perilaku pencucian, } \\
\text { sehingga ukuran pada produk dan } \\
\text { kualitas pekerjaan tangan yang } \\
\text { diaplikasikan tidak akan berubah. }\end{array}$ \\
\hline 3. & $\begin{array}{l}\text { Desain untuk noda } \\
\text { (design for stain) }\end{array}$ & $\begin{array}{l}\text { Material yang diadopsi merupakan } \\
\text { material bekas dan memiliki gambar } \\
\text { serta merek dari kantong bekas } \\
\text { semen itu sendiri. Dengan } \\
\text { pengaplikasian teknik pilin dan } \\
\text { teknik makrame, mendorong produk } \\
\text { untuk memperlihatkan noda bekas } \\
\text { sebelumnya. }\end{array}$ \\
\hline 4. & $\begin{array}{l}\text { Penyetrikaan daya } \\
\text { rendah (low iron) }\end{array}$ & $\begin{array}{l}\text { Dengan produk makrame dari } \\
\text { pilinan ini tidak memerlukan } \\
\text { tindakan penyetrikaan karena } \\
\text { struktur material yang kaku, tidak } \\
\text { berubah, dan tidak akan kusut. }\end{array}$ \\
\hline
\end{tabular}

\section{KESIMPULAN}

Kertas bekas kantong semen dapat diolah menjadi material bermanfaat dan layak pakai, salah satu pengaplikasiannya ada pada produk fashion busana dan tas. Material dibuat menggunakan alat - alat sederhana dan teknik yang sudah ada sebelumnya. Material yang dihasilkan merupakan pilinan panjang yang direkatkan menggunakan zat perekat dan memiliki karakter yang cukup fleksibel serta kuat untuk diolah menjadi produk busana dan tas. Teknik yang diaplikasikan merupakan teknik makrame yang bertujuan memberi pori produk dan menciptakan bentuk visual baru pada produk fashion. Material kertas bekas kantong semen hasil eksplorasi dapat digolongkan material ramah lingkungan.

Tahapan yang dilakukan dalam pembuatan produk fashion berupa busana dan tas dari material olahan kertas bekas kantong semen dapat meningkatkan nilai ekonomis dan kualitas material itu sendiri. Pemanfaatan material juga dapat meminimalisir dampak negatif pada lingkungan. Namun, produk busana dan tas yang dihasilkan belum termasuk $100 \%$ produk ramah lingkungan karena menggunakan zat perekat untuk 
merekatkan sambungan pilinan. Dikarenakan keterbatasan untuk mencari zat perekat yang ramah lingkungan sejenis.

\section{REFERENSI}

[1]. Fletcher K, and Grose L. 2012. Fashion \& Sustainability : Design for Change. London: Laurence King Pub;

[2]. Ray N, W U J, and R E. 2009. Alternatif Penggunaan Limbah Pabrik Kertas Sebagai Pengganti Sebagian Semen (Cementitous) Dalam Pembuatan Beton. Dinamika Teknik Sipil [Internet]. 9(1):48-55. Available from: https://publikasiilmiah.ums.ac.id/bitstream/handle/11617/229/_8_Norman R_ ITATS_ok_pdf?sequence=1\&isAllowed $=y$

[3]. Gunarto A, Satyarno I, and Tjokrodimuljo K. 2008. Pemanfaatan Limbah Kertas Koran Untuk Pembuatan Panel Papercrete. Forum Teknik Sipil [Internet]. 18.

Available from:

https://www.researchgate.net/publication/279664218_PEMANFAATAN_LIMBAH_K ERTAS_KORAN_UNTUK_PEMBUATAN_PANEL_PAPERCRETE

[4]. Anam C, Nugraha L, and Rochman AN. 2018. Pemanfaatan Kantong Semen dan Kayu Laser Sebagai Produk Tas untuk Meningkatkan Kreatifitas dan Nilai Jual di UKM Viora Tanggulangin, Sidoarjo. Jurnal Rekarupa [Internet]. 5(1):11-21. Available from: https://ejurnal.itenas.ac.id/index.php/rekarupa/article/view/2354/1831 